\title{
PHYTOREMEDIATION TECHNOLOGIES APPLICABLE TO AQUATIC REQUIREMENT (AN OVERVIEW)
}

\author{
Felix Stolberg \\ Anastasiia Zadniprovska \\ Kharkiv National Academy of Municipal Economy, Ukraine
}

\begin{abstract}
The purpose of this paper is to provide a concise discussion of the processes associated with the use of water phytoremediation as a cleanup or containment technique for remediation of contaminated water bodies. The different forms of water phytoremediation are defined and their applications are discussed. The types of contaminants that are appropriate for phytoremediation are summarized. Information is provided on the types of vegetation that can be used in water phytoremediation. The advantages and disadvantages of phytoremediation methods are discussed too.
\end{abstract}

\section{KEYWORDS}

Rhizofiltration, Hydraulic control, Phytovolatilization, Riparian corridors / Buffer strips, Phytodegradation (Phytotransformation), Phytoextraction, Rhizodegradation (Plant-assisted bioremediation), Constructed wetland (Treatment wetland).

\section{INTRODUCTION}

Every year large amounts of waste is released into the environment and a significant number of pollutants remain in the environment causing widespread soil and fresh water pollution.

International organizations (as FAO, WHO, etc) have always paid great attention to wastewater treatment and its implications when used for sustainable agricultural development with a view to water quality and has studied the use of drainage water for irrigation, wastewater treatment and its reuse in agriculture, and water quality and health.

Since 1975, from all around the world, public and private research organizations and several university institutes have been turning their attention to alternative biotechnologies for the treatment of organic sewage, thus reducing the polluting charge and making it safe for the environment; one of these is phytoremediation.

Today, phytoremediation systems represent the real alternative for the reclamation of wastewater and its reuse in agriculture for safe food production linked to a healthy human nutrition and environmental surface water quality management.

The phytoremediation industry is moving into several treatment markets: municipal, agroidustrial, zootechnical and into the treatment of organic and inorganic pollutants present in surface waters (rivers, lakes, etc). 
Even though phytoremediation appears to have limited application, researchers in industry, academia, and government are looking into phytoremediation as a useful treatment technology. In fact, a number of companies that offer phytoremediation technologies have been started in the last few years, and many larger consulting firms are beginning to offer phytoremediation services as well.

\section{OVERVIEW OF PHYTOREMEDIATION}

Phytoremediation is an emerging technology which uses plants and their associated rhizospheric microorganisms to remove, degrade, or contain chemical contaminants located in the soil, sediments, groundwater, surface water, and even the atmosphere. Researchers have found that plants can be used to treat most classes of contaminants, including petroleum hydrocarbons, chlorinated solvents, pesticides, metals, radionuclides, explosives, and excess nutrients. Plant species are selected for phytoremediation based on their potential to evapotranspirate groundwater, the degradative enzymes they produce, their growth rates and yield, the depth of their root zone, and their ability to bioaccumulate contaminants.

Phytoremediation is actually a broad class of remediation techniques which include many treatment strategies. Obviously, the common thread through all of phytoremediation techniques is the use of plants to treat a contaminant problem. However, due to the diverse nature of chemical contamination and the diversity of plants with the potential to treat them, remedial project managers must choose between a wide variety of phytoremediation techniques to solve the problem at hand.

Despite the diversity of phytoremediation technologies, its application is limited by a number of factors. Phytoremediation can only work at sites that are well suited for plant growth. This means that the concentration of pollutants cannot be toxic to the plants, and the pollution cannot be so deep in the soils or groundwater that plant roots cannot reach it. As a result, phytoremediation may be a good strategy for sites conducive to plant growth with shallow contamination, it may be a good secondary or tertiary phase in a treatment train for highly polluted sites, it may form a buffer area for emergency use, or it may not be a viable option for a site.

Table 1 lists the various types of phytoremediation technologies applicable for contaminated water treatment.

At a phytoremediation site, combinations of the phytoremediation processes mentioned above may occur simultaneously or in sequence for a particular contaminant, or different processes may act on different contaminants or at different exposure concentrations. For example, TCE in soil can be subject to biodegradation in the root zone (rhizodegradation) and metabolism within the plant (phytodegradation), with loss of some contaminant or metabolite through volatilization from the plant (phytovolatilization). Some metals or radionuclides in water can be accumulated on or within roots (rhizofiltration) while other metals or radionuclides are simultaneously taken up into the aerial portion of the plant (phytoextraction). 
Table 1. Types of Water Phytoremediation Systems. Comparison Table

\begin{tabular}{|c|c|c|c|c|}
\hline $\begin{array}{c}\text { Treatment } \\
\text { Method }\end{array}$ & Advantages & Disadvantages & Media & Contaminants \\
\hline 1 & 2 & 3 & 4 & 5 \\
\hline $\begin{array}{l}\text { Rhizo- } \\
\text { filtration }\end{array}$ & $\begin{array}{l}\text { - Either terrestrial or aquatic plants can be used. Although } \\
\text { terrestrial plants require support, such as a floating } \\
\text { platform, they generally remove more contaminants than } \\
\text { aquatic plants; } \\
\text { - This system can be either in situ (floating rafts on } \\
\text { ponds) or ex situ (an engineered tank system); } \\
\text { - An ex situ system can be placed anywhere because the } \\
\text { treatment does not have to be at the original location of } \\
\text { contamination. }\end{array}$ & $\begin{array}{l}\text { - The pH of the influent solution may have to be } \\
\text { continually adjusted to obtain optimum metals } \\
\text { uptake; } \\
\text { - The chemical speciation and interaction of all } \\
\text { species in the influent have to be understood and } \\
\text { accounted for; } \\
\text { - A well-engineered system is required to control } \\
\text { influent concentration and flow rate; } \\
\text { - The plants (especially terrestrial plants) may have } \\
\text { to be grown in a greenhouse or nursery and then } \\
\text { placed in the rhizofiltration system; } \\
\text { - Periodic harvesting and plant disposal are required; } \\
\text { - Metal immobilization and uptake results from } \\
\text { laboratory and greenhouse studies might not be } \\
\text { achievable in the field. }\end{array}$ & $\begin{array}{l}\text { surface water and } \\
\text { water pumped } \\
\text { through troughs }\end{array}$ & $\begin{array}{l}\text { Metals: } \mathrm{Pb}, \mathrm{Cd}, \mathrm{Cu}, \mathrm{Fe}, \mathrm{Ni} \\
\mathrm{Mn}, \mathrm{Zn}, \mathrm{Cr}(\mathrm{VI}) \\
\text { Radionuclides: } \\
{ }^{230} \mathrm{Sr},{ }^{137} \mathrm{Cs}, \\
{ }^{236} \mathrm{U}\end{array}$ \\
\hline $\begin{array}{l}\text { Hydraulic } \\
\text { Control }\end{array}$ & $\begin{array}{l}\text { - An engineered pump-and-treat system does not need to } \\
\text { be installed; } \\
\text { - Costs will be lower; } \\
\text { - Roots will penetrate into and be in contact with a much } \\
\text { greater volume of soil than if a pumping well is used; }\end{array}$ & $\begin{array}{l}\text { - Water uptake by plants is affected by climatic and } \\
\text { seasonal conditions; thus, the rate of water uptake } \\
\text { will not be constant. Water uptake by deciduous trees } \\
\text { will slow considerably during winter; } \\
\text { - Ground water removal is limited by the root depth } \\
\text { of the vegetation. }\end{array}$ & $\begin{array}{l}\text { groundwater, } \\
\text { surface water, and } \\
\text { soil water }\end{array}$ & $\begin{array}{l}\text { Water-soluble leachable } \\
\text { organics and inorganics are } \\
\text { used at concentrations that } \\
\text { are not phytotoxic }\end{array}$ \\
\hline
\end{tabular}




\begin{tabular}{|c|c|c|c|c|}
\hline & & & & Table 1 (Continu \\
\hline 1 & 2 & 3 & 4 & 5 \\
\hline $\begin{array}{l}\text { Phyto- } \\
\text { volati- } \\
\text { lization }\end{array}$ & $\begin{array}{l}\text { - Contaminants could be transformed to less-toxic } \\
\text { forms, such as elemental mercury and dimethyl } \\
\text { selenite gas; } \\
\text { - Contaminants or metabolites released to the } \\
\text { atmosphere might be subject to more effective or } \\
\text { rapid natural degradation processes such as } \\
\text { photodegradation. }\end{array}$ & $\begin{array}{l}\text { - The contaminant or a hazardous metabolite (such as vinyl } \\
\text { chloride formed from TCE) might be released into the } \\
\text { atmosphere. One study indicated TCE transpiration, but other } \\
\text { studies found no transpiration; } \\
\text { - The contaminant or a hazardous metabolite might } \\
\text { accumulate in vegetation and be passed on in later products } \\
\text { such as fruit or lumber. Low levels of metabolites have been } \\
\text { found in plant tissue }\end{array}$ & $\begin{array}{l}\text { groundwat } \\
\text { er, but it } \\
\text { can be } \\
\text { applied to } \\
\text { soil, } \\
\text { sediments, } \\
\text { and } \\
\text { sludges }\end{array}$ & $\begin{array}{l}\text { Organics: TCE, } 1,1,1- \\
\text { trichloroethane (TCA) and carbon } \\
\text { tetrachloride } \\
\text { Inorganics: } \mathrm{Se}, \mathrm{Hg}, \mathrm{As}\end{array}$ \\
\hline $\begin{array}{l}\text { Riparian } \\
\text { Corridors / } \\
\text { Buffer } \\
\text { Strips }\end{array}$ & $\begin{array}{l}\text { Secondary advantages include the stabilization of } \\
\text { stream banks and prevention of soil erosion. } \\
\text { Aquatic and terrestrial habitats are greatly } \\
\text { improved by riparian forest corridors. }\end{array}$ & $\begin{array}{l}\text { The use of buffer strips might be limited to easily assimilated } \\
\text { and metabolized compounds. Land use constraints may } \\
\text { restrict application. }\end{array}$ & $\begin{array}{l}\text { surface } \\
\text { water and } \\
\text { ground- } \\
\text { water }\end{array}$ & $\begin{array}{l}\text { Nutrient and pesticide } \\
\text { contaminants are among the water- } \\
\text { soluble organics and inorganics } \\
\text { studied the most often sing this } \\
\text { technology. }\end{array}$ \\
\hline $\begin{array}{l}\text { Phyto- } \\
\text { degradation } \\
\text { or Phyto- } \\
\text { transfor- } \\
\text { mation }\end{array}$ & $\begin{array}{l}\text { Contaminant degradation due to enzymes } \\
\text { produced by a plant can occur in an environment } \\
\text { free of microorganisms (for example, an } \\
\text { environment in which the microorganisms have } \\
\text { been killed by high contaminant levels). Plants are } \\
\text { able to grow in sterile soil and also in soil that has } \\
\text { concentration levels that are toxic to } \\
\text { microorganisms. Thus, phytodegradation } \\
\text { potentially could occur in soils where } \\
\text { biodegradation cannot. }\end{array}$ & $\begin{array}{l}\text { - Toxic intermediates or degradation products may form. In a } \\
\text { study unrelated to phytoremediation research, PCP was } \\
\text { metabolized to the potential mutagen tetrachlorocatechol in } \\
\text { wheat plants and cell cultures; } \\
\text { - The presence or identity of metabolites within a plant might } \\
\text { be difficult to determine; thus contaminant destruction could } \\
\text { be difficult to confirm. }\end{array}$ & $\begin{array}{l}\text { soil, } \\
\text { sediments, } \\
\text { sludges, } \\
\text { and } \\
\text { groundwat } \\
\text { er. Surface } \\
\text { water can } \\
\text { also be } \\
\text { remediate } \\
\text { d using } \\
\text { phyto- } \\
\text { degradatio } \\
\text { n }\end{array}$ & $\begin{array}{l}\text { Organics: TCE, TNT, atrazine, } \\
\text { 2,4-dichlorophenoxyacetic acid, } \\
\text { 2,4,5-trichlorophenoxyacetic acid, } \\
\text { 4-chloroaniline, 3,4- } \\
\text { dichloroaniline, PCP, diethyl- } \\
\text { hexylphthalate (DEHP), perylene, } \\
\text { benzo(a)pyrene, } \\
\text { hexachlorobenzene, DDT, PCBs, } \\
\text { methyl, tertiary-butylbentazon, }\end{array}$ \\
\hline
\end{tabular}


Table 1 (Continue)

\begin{tabular}{|c|c|c|c|c|}
\hline 1 & 2 & 3 & 4 & 5 \\
\hline & & & & $\begin{array}{l}\text { 2,4-dichlorophenol } \\
\text { Inorganics: nutrients }\end{array}$ \\
\hline Phytoextraction & $\begin{array}{l}\text { The plant biomass containing the } \\
\text { extracted contaminant can be a } \\
\text { resource. For example, biomass } \\
\text { that contains selenium (Se), an } \\
\text { essential nutrient, has been } \\
\text { transported to areas that are } \\
\text { deficient in Se and used for animal } \\
\text { feed. }\end{array}$ & $\begin{array}{l}\text { - Metal hyperaccumulators are generally slow- } \\
\text { growing with a small biomass and shallow root } \\
\text { systems. } \\
\text { - Plant biomass must be harvested and removed, } \\
\text { followed by metal reclamation or proper disposal of } \\
\text { the biomass; } \\
\text { - Metals may have a phytotoxic effect; } \\
\text { - Phytoextraction studies conducted using } \\
\text { hydroponicallygrown plants, with the contaminant } \\
\text { added in solution, may not reflect actual conditions } \\
\text { and results occurring in soil. }\end{array}$ & $\begin{array}{l}\text { is primarily used in } \\
\text { the treatment of } \\
\text { soil, sediments, } \\
\text { and sludges. It can } \\
\text { be used to a lesser } \\
\text { extent for } \\
\text { treatment of } \\
\text { contaminated } \\
\text { water }\end{array}$ & $\begin{array}{l}\text { Metals: } \mathrm{Ag}, \mathrm{Cd}, \mathrm{Co}, \mathrm{Cr}, \mathrm{Cu} \text {, } \\
\mathrm{Hg}, \mathrm{Mn}, \mathrm{Mo}, \mathrm{Ni}, \mathrm{Pb}, \mathrm{Zn} \text {; } \\
\text { Metalloids: } \mathrm{As}, \mathrm{Se} ; \\
\text { Radionuclides: }{ }^{90} \mathrm{Sr},{ }^{137} \mathrm{Cs} \text {, } \\
{ }^{239} \mathrm{Pu},{ }^{238} \mathrm{U},{ }^{234} \mathrm{U} ; \\
\text { Nonmetals: } \mathrm{B} .\end{array}$ \\
\hline $\begin{array}{l}\text { Vhizodegradation or Plant- } \\
\text { Assisted Bioremediation }\end{array}$ & $\begin{array}{l}\text { - Contaminant destruction occurs } \\
\text { in situ; } \\
\text { - Translocation of the compound to } \\
\text { the plant or atmosphere is less } \\
\text { likely than with other } \\
\text { phytoremediation technologies } \\
\text { since degradation occurs at the } \\
\text { source of the contamination; } \\
\text { - Mineralization of the } \\
\text { contaminant can occur; } \\
\text { - Low installation and maintenance } \\
\text { cost as compared to other remedial } \\
\text { options. }\end{array}$ & $\begin{array}{l}\text { - Development of an extensive root zone is likely to } \\
\text { require substantial time; } \\
\text { - Root depth can be limited due to the physical } \\
\text { structure or moisture conditions of the soil; } \\
\text { - The rhizosphere might effect an increase in the } \\
\text { initial rate of degradation compared to a } \\
\text { nonrhizosphere soil, but the final extent or degree of } \\
\text { degradation might be similar in both rhizosphere and } \\
\text { nonrhizosphere soil; } \\
\text { - Plant uptake can occur for many of the } \\
\text { contaminants that have been studied; } \\
\text { - The plants need additional fertilization because of } \\
\text { microbial competition for nutrients; }\end{array}$ & $\begin{array}{l}\text { soils, groundwater } \\
\text { within the } \\
\text { rhizosphere }\end{array}$ & $\begin{array}{l}\text { Organics: TPH, PAHs, } \\
\text { BTEX, Pesticides, } \\
\text { Chlorinated solvents, PCP, } \\
\text { PCBs, Surfactants. }\end{array}$ \\
\hline
\end{tabular}


Table 1 (Continued)

\begin{tabular}{|c|c|c|c|c|}
\hline 1 & 2 & 3 & 4 & 5 \\
\hline & & $\begin{array}{l}\text { - The exudates might stimulate microorganisms that } \\
\text { are not degraders, at the expense of degraders; } \\
\text { - Organic matter from the plants may be used as a } \\
\text { carbon source instead of the contaminant, which } \\
\text { could decrease the amount of contaminant } \\
\text { biodegradation. }\end{array}$ & & \\
\hline $\begin{array}{l}\text { Constructed } \\
\text { wetlands or } \\
\text { treatment } \\
\text { wetland }\end{array}$ & \multicolumn{2}{|c|}{$\begin{array}{l}\text { Phytoremediation methods used in treatment wetlands may be different and they can also be combined. So } \\
\text { advantages and disadvantages of constructed wetlands are depend on the phytoremediation method used. Among } \\
\text { generalized advantages can be named: } \\
\text { - Construction and maintenance is cheap and easy; } \\
\text { - Water safe reclamation and reuse without other treatments; } \\
\text { - Capacity of pollutant removal is nearly constant and unaffected by seasonal conditions; } \\
\text { - Constructed wetlands create an environment suitable for the habitat and breeding of birds and other natural } \\
\text { typical animals in wetlands; } \\
\text { - Constructed wetlands are useful for the control of erosion and desertification. } \\
\text { The main disadvantage of constructed wetlands is the large surface area needed for it. }\end{array}$} & $\begin{array}{l}\text { surface water, } \\
\text { municipal waste } \\
\text { water, domestic } \\
\text { sewage, refinery } \\
\text { effluents, acid } \\
\text { mine drainage, or } \\
\text { landfill leachate }\end{array}$ & \\
\hline
\end{tabular}


Phytoremediation applications can be classified based on the contaminant fate: degradation, extraction, containment, or a combination of these. Phytoremediation applications can also be classified based on the mechanisms involved. Such mechanisms include extraction of contaminants from soil or groundwater; concentration of contaminants in plant tissue; degradation of contaminants by various biotic or abiotic processes; volatilization or transpiration of volatile contaminants from plants to the air; immobilization of contaminants in the root zone; hydraulic control of contaminated groundwater (plume control); and control of runoff, erosion, and infiltration by vegetative covers. A brief explanation of these application categories follows, with more detailed explanations in following chapters.

\subsection{Degradation}

Plants may enhance degradation in the rhizosphere (root zone of influence). Microbial counts in rhizosphere soils can be 1 or 2 orders of magnitude greater than in nonrhizosphere soils. It is not known whether this is due to microbial or fungal symbiosis with the plant, plant exudates including enzymes, or other physical/chemical effects in the root zone. There are, however, measurable effects on certain contaminants in the root zone of planted areas. Several projects examine the interaction between plants and such contaminants as trinitrotoluene (TNT), total petroleum hydrocarbons (TPH), pentachlorophenol (PCP), and polynuclear aromatic hydrocarbons (PAH). Another possible mechanism for contaminant degradation is metabolism within the plant. Some plants may be able to take in toxic compounds and in the process of metabolizing the available nutrients, detoxify them. Trichloroethylene (TCE) is possibly degraded in poplar trees and the carbon used for tissue growth while the chloride is expelled through the roots. EPA has three projects underway in the field using populus species to remediate TCE. Tests at the University of Washington are being developed to verify this degradation mechanism under controlled conditions.

\subsection{Extraction}

Phytoextraction, or phytomining, is the process of planting a crop of a species that is known to accumulate contaminants in the shoots and leaves of the plants, and then harvesting the crop and removing the contaminant from the site. Unlike the destructive degradation mechanisms, this technique yields a mass of plant and contaminant (typically metals) that must be transported for disposal or recycling. This is a concentration technology that leaves a much smaller mass to be disposed of when compared to excavation and landfilling. This technology is being evaluated in a Superfund Innovative Technology Evaluation (SITE) demonstration, and may also be a technology amenable to contaminant recovery and recycling. Rhizofiltration is similar to phytoextraction in that it is also a concentration technology. It differs from phytoextraction in that the mechanism is root accumulation and harvest using hydroponic (soil-less) growing techniques. This is useful for separating metal contaminants from water. Rhizofiltration has been demonstrated on U.S. Department of Energy (DOE) sites for radionuclides.

Volatilization or transpiration through plants into the atmosphere is another possible mechanism for removing a contaminant from the soil or water of a site. It is often raised as a concern in response to a proposed phytoremediation project, but has not been shown to be an actual pathway for many contaminants. Mercury $(\mathrm{Hg})$ has been shown to move through a plant and into the air in a plant that was genetically altered to allow it to do so. The thought behind this media switching is that elemental $\mathrm{Hg}$ in the air poses less risk than other $\mathrm{Hg}$ forms in the soil. However, the technology or the associated risk has not been evaluated. 


\section{PHYTOREMEDIATION TECHNOLOGIES}

This chapter presents a literature review and evaluation of the major water phytoremediation processes or technologies. The technologies presented represent the major, significant, or widely studied forms of phytoremediation. It is divided into subsections that present definitions, mechanisms, site characteristics, applicable media, and contaminants amenable to each process, and the associated concentrations where available. The advantages and disadvantages of each process are also discussed.

\subsection{Rhizofiltration}

Rhizofiltration is the adsorption or precipitation onto plant roots, or absorption into the roots of contaminants that are in solution surrounding the root zone, due to biotic or abiotic processes. Plant uptake, concentration, and translocation might occur, depending on the contaminant. Exudates from the plant roots might cause precipitation of some metals. Rhizofiltration first results in contaminant containment, in which the contaminants are immobilized or accumulated on or within the plant. Contaminants are then removed by physically removing the plant.

\subsection{Hydraulic Control}

Hydraulic control is the use of plants to remove groundwater through uptake and consumption in order to contain or control the migration of contaminants. Hydraulic control is also known as phytohydraulics or hydraulic plume control.

\subsection{Phytovolatilization}

Phytovolatilization is the uptake and transpiration of a contaminant by a plant, with release of the contaminant or a modified form of the contaminant to the atmosphere from the plant through contaminant uptake, plant metabolism, and plant transpiration. Phytodegradation is a related phytoremediation process that can occur along with phytovolatilization.

\subsection{Riparian Corridors/Buffer Strips}

Riparian corridors/buffer strips are generally applied along streams and river banks to control and remediate surface runoff and groundwater contamination moving into the river. These systems can also be installed to prevent down gradient migration of a contaminated groundwater plume and to degrade contaminants in the plume. Mechanisms for remediation include water uptake, contaminant uptake, and plant metabolism. Riparian corridors are similar in conception to physical and chemical permeable barriers such as trenches filled with iron filings, in that they treat groundwater without extraction containment. Riparian corridors and buffer strips may incorporate certain aspects of hydraulic control, phytodegradation, rhizodegradation, phytovolatilization, and perhaps phytoextraction.

\subsection{Phytodegradation}

Phytodegradation (also known as phytotransformation) is the breakdown of contaminants taken up by plants through metabolic processes within the plant, or the breakdown of contaminants external to the plant through the effect of compounds (such as enzymes) produced by the plants. The main mechanism is plant uptake and metabolism. Additionally, degradation may occur outside the plant, due to the release of compounds that cause transformation. Any degradation caused by microorganisms associated with or affected by the plant root is considered rhizodegradation. 


\subsection{Phytoextraction}

Phytoextraction is the uptake of contaminants by plant roots and translocation within the plants. Contaminants are generally removed by harvesting the plants. This concentration technology leaves a much smaller mass to be disposed of than excavation of the soil or other media does. This technology is most of ten applied to metal-contaminated soil.

\subsection{Rhizodegradation}

Rhizodegradation is the breakdown of an organic contaminant in soil through microbial activity that is enhanced by the presence of the root zone. Rhizodegradation is also known as plant-assisted degradation, plant-assisted bioremediation, plant-aided in situ biodegradation, and enhanced rhizosphere biodegradation.

Root-zone biodegradation is the mechanism for implementing rhizodegradation. Root exudates are compounds produced by plants and released from plant roots. They include sugars, amino acids, organic acids, fatty acids, sterols, growth factors, nucleotides, flavanones, enzymes, and other compounds (Shimp et al. 1993; Schnoor et al. 1995a). The microbial populations and activity in the rhizosphere can be increased due to the presence of these exudates, and can result in increased organic contaminant biodegradation in the soil. Additionally, the rhizosphere substantially increases the surface area where active microbial degradation can be stimulated. Degradation of the exudates can lead to cometabolism of contaminants in the rhizosphere.

Plant roots can affect soil conditions by increasing soil aeration and moderating soil moisture content, thereby creating conditions more favorable for biodegradation by indigenous microorganisms. Thus, increased biodegradation could occur even in the absence of root exudates. One study raised the possibility that transpiration due to alfalfa plants drew methane from a saturated methanogenic zone up into the vadose zone where the methane was used by methanotrophs that cometabolically degraded TCE (Narayanan et al. 1995).

The chemical and physical effects of the exudates and any associated increase in microbial populations might change the soil $\mathrm{pH}$ or affect the contaminants in other ways.

\subsection{Constructed Wetlands}

Constructed wetlands or treatment wetlands are artificial wetlands that are used for treating organic, inorganic, and nutrient contaminants in contaminated surface water, municipal waste water, domestic sewage; refinery effluents, acid mine drainage, or landfill leachate. Phytoremediation methods used in treatment wetlands may be different and they can also be combined. A considerable amount of research and applied work has been conducted using constructed wetlands for these applications. Cole (1998) provides an overview of constructed wetlands, and more detailed discussions are provided in Kadlec and Knight (1996). Natural wetlands have also been examined for treatment of these wastes. Ground-water treatment is less common, though conceivable. Except in a few cases, constructed wetlands generally have not been used in remediation of hazardous waste sites; however, constructed and natural wetlands have been investigated for the phytodegradation of munitions-contaminated water. In the future, constructed wetlands might become an option for treatment of water extracted from hazardous waste sites, using rhizofiltration and phytodegradation. Integration of hazardous waste site phytoremediation and constructed wetland technologies might increase in the future.

There are a number of different forms of phytoremediation, discussed above. Defining these forms is useful to clarify and understand the different processes that can occur due to 
vegetation, what happens to a contaminant, where the contaminant remediation occurs, and what should be done for effective phytoremediation. The different forms of phytoremediation may apply to specific types of contaminants or contaminated media, and may require different types of plants.

\section{CONCLUSIONS}

The purpose of this paper is to provide a concise discussion of the processes associated with the use of water phytoremediation as a cleanup or containment technique for remediation of contaminated sites. Introductory material on plant processes is provided. The different forms of water phytoremediation are defined and their applications are discussed. The types of contaminated media and contaminants that are appropriate for phytoremediation are summarized. Information is provided on the types of vegetation that have been studied or used in phytoremediation. The advantages and disadvantages of phytoremediation are discussed too.

Phytoremediation is the use of plants to partially or substantially remediate selected contaminants in contaminated soil, sludge, sediment, ground water, surface water, and waste water. It utilizes a variety of plant biological processes and the physical characteristics of plants to aid in site remediation. Phytoremediation has also been called green remediation, botano-remediation, agroremediation, and vegetative remediation.

Phytoremediation is a integration of processes, with the different processes occurring to differing degrees for different conditions, media, contaminants, and plants. A variety of terms have been used in the literature to refer to these various processes. This discussion defines and uses a number of terms as a convenient means of introducing and conceptualizing the processes that occur during phytoremediation. However, it must be realized that the various processes described by these terms all tend to overlap to some degree and occur in varying proportions during phytoremediation. Phytoremediation encompasses a number of different methods that can lead to contaminant degradation, removal (through accumulation or dissipation), or immobilization.

\section{REFERENCES}

[1] Phytoremediation of TCE using Populus http://207.86.51.66/download/studentpapers/phytotce.pdf

[2] Introduction to Phytoremediation http://clu-in.org/download/remed/introphyto.pdf

[3] Phytoremediation of Contaminated Soil and Ground Water at Hazardous Waste Sites http://www.epa.gov/ada/download/issue/epa_540_s01_500.pdf http://www.waterwaste-environment-marketplace.com/details.asp? cid=13943

[4] Giannotti M. Water Reclamation \& Phyto-technologies, Litocart: Cellole, 2005 